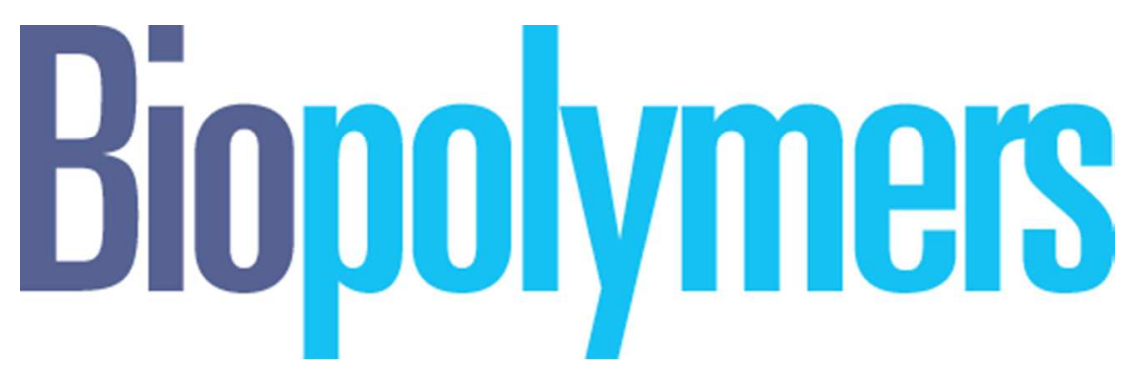

\title{
BROMOTRYPTOPHANS AND THEIR INCORPORATION IN CYCLIC AND BICYCLIC PRIVILEGED PEPTIDES
}

\begin{tabular}{|r|l|}
\hline Journal: & Biopolymers \\
\hline Manuscript ID & BIP-2017-0166.R2 \\
\hline Wiley - Manuscript type: & Original Article \\
\hline Date Submitted by the Author: & n/a \\
\hline Complete List of Authors: & $\begin{array}{l}\text { Garcia-Pindado, Julia; Institute for Research in Biomedicine (IRB } \\
\text { Barcelona), Barcelona Institute of Science and Technology (BIST) } \\
\text { Willemse, Tom; Vrije Universiteit Brussel, Departments of Chemistry and } \\
\text { Bio-engineering Sciences; University of Antwerp, Organic Synthesis } \\
\text { Goss, Rebecca; University of St Andrews, School of Chemistry and BSRC } \\
\text { Maes, Bert; University of Antwerp, Organic Synthesis } \\
\text { Giralt, Ernest; Institut de Recerca Biomedica, chemistry } \\
\text { Ballet, Steven; Vrije Universiteit Brussel, Departments of Chemistry and } \\
\text { Bio-engineering Sciences } \\
\text { Teixidó, Meritxell; Institute for Research in Biomedicine (IRB Barcelona), } \\
\text { Barcelona Institute of Science and Technology (BIST) }\end{array}$ \\
\hline Keywords: & $\begin{array}{l}\text { solid-phase peptide synthesis, tryptophan, bromination, on-resin Miyaura } \\
\text { and Suzuki cross-coupling, PAMPA and biostability }\end{array}$ \\
\hline
\end{tabular}



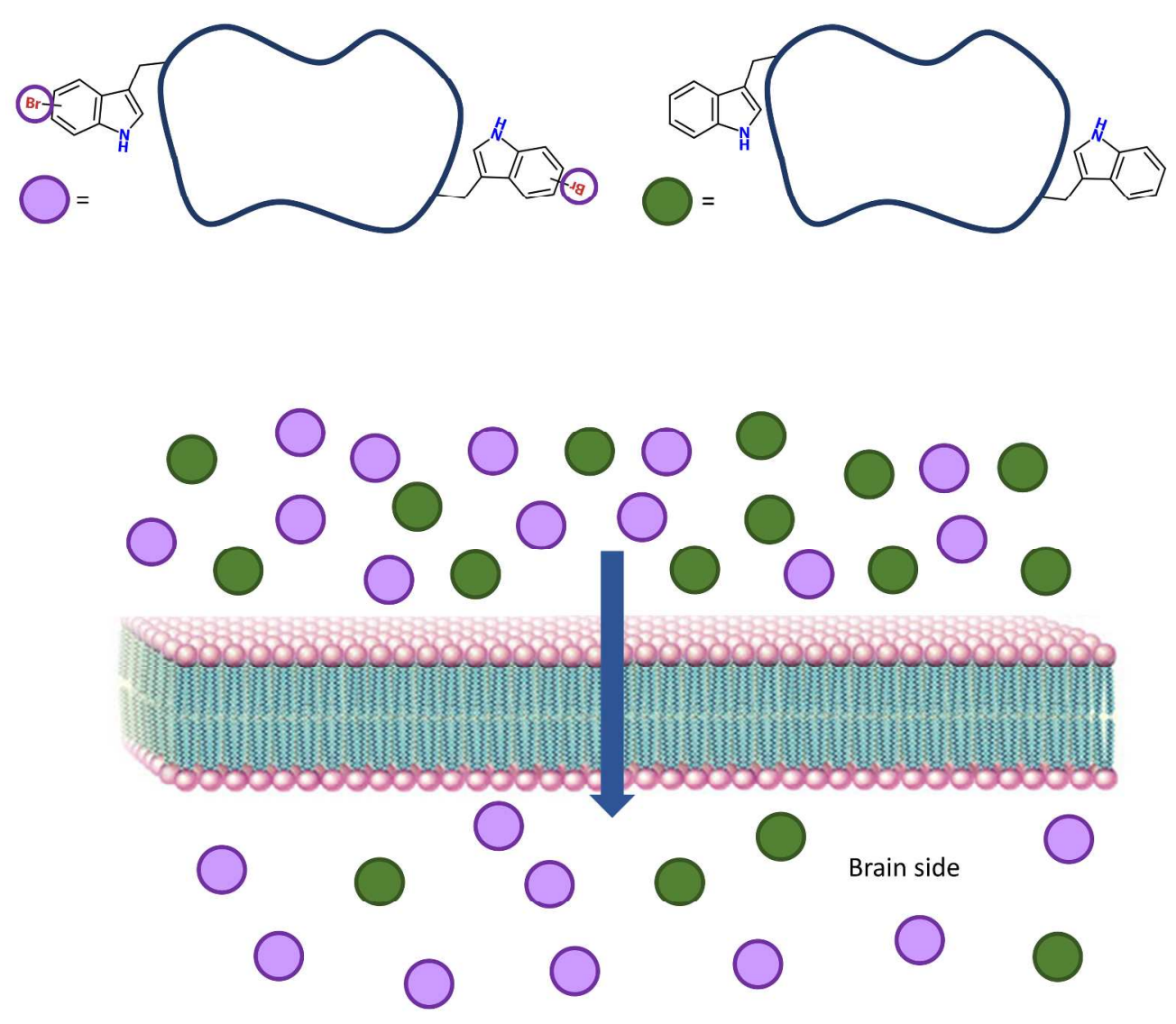

$260 \times 260 \mathrm{~mm}(300 \times 300 \mathrm{DPI})$

John Wiley \& Sons, Inc. 


\title{
BROMOTRYPTOPHANS AND THEIR INCORPORATION IN CYCLIC AND BICYCLIC PRIVILEGED PEPTIDES
}

\author{
Júlia García-Pindado ${ }^{a}$, Tom Willemse ${ }^{b, c}$, Rebecca Goss ${ }^{d}$, Bert U. W. Maes ${ }^{c}$, Ernest Giralt ${ }^{a, e^{*}}$, Steven \\ Ballet $^{\mathrm{b}^{*}}$, Meritxell Teixidó ${ }^{\mathrm{a*}}$ \\ a Institute for Research in Biomedicine (IRB Barcelona), Barcelona Institute of Science and Technology \\ (BIST), 08028, Barcelona, Spain \\ ${ }^{\mathrm{b}}$ Research Group of Organic, Departments of Chemistry and Bioengineering Sciences, Vrije Universiteit \\ Brussel, 1050, Brussels, Belgium \\ c Organic Synthesis, University of Antwerp, B-2020, Antwerp, Belgium \\ ${ }^{d}$ School of Chemistry and BSRC, University of St Andrews, KY16 9ST, St Andrews, United Kingdom \\ e Department of Organic Chemistry, University of Barcelona, 08028, Barcelona, Spain
}

\begin{abstract}
:
While revisiting biologically active natural peptides, the importance of the tryptophan residue became clear. In this article, the incorporation of this amino acid, brominated at different positions of the indole ring, into cyclic peptides was successfully achieved. These products demonstrated improved properties in terms of passive diffusion, permeability across membranes, biostability in human serum and cytotoxicity. Moreover, these brominated tryptophans at positions 5, 6 or 7 proved to be compatible as building blocks to prepare bicyclic stapled peptides by performing on-resin Suzuki-Miyaura crosscoupling reactions.
\end{abstract}

Keywords: solid-phase peptide synthesis; tryptophan; bromination; on-resin Miyaura and SuzukiMiyaura cross-coupling; PAMPA; biostability

\section{INTRODUCTION:}

The relevance of the amino acid tryptophan is widely known in the field of natural products, as this particular building block represents an important biosynthetic precursor for some bioactive compounds such as alkaloids ${ }^{1}$. Additionally, a common feature of membrane-spanning proteins is their preference for aromatic amino acids, namely tyrosine or tryptophan ${ }^{2,3}$. Aromatic, as well as charged, amino acids may act as an anchor for these proteins while they also participate in interfacial interactions ${ }^{4}$. The indole ring of tryptophan can display $\pi$-cation interactions, which are known to be of high importance in biological systems and are of increasing interest in medicinal chemistry. These interactions are present in $65 \%$ of the protein interfaces ${ }^{5}$ and are considered to be real driving forces in biological processes. Stability and folding of proteins ${ }^{6}$ along with specific drug-receptor interactions ${ }^{7}$ have been related to $\pi$ cation interactions.

The presence of tryptophan in peptides and proteins is crucial for their biological activity despite their low natural abundance (less than $1 \%$ of amino acids) ${ }^{8}$. At the beginning of the $21^{\text {st }}$ century, novel substitution patterns within tryptophan were discovered, thus providing structures that are not directly accessible for ribosomes, including post-translationally modified analogues. Ribosomally synthesized and post-translationally modified peptides (RiPPs) comprise constrained peptides with improved 
pharmacological properties such as higher stability, functionality and target recognition ${ }^{9}$. Those biologically active peptides are formed through a rich variety of post-translational modification chemistries, some of them involving tryptophan derivatization. Position 3 of tryptophan can, for example, be isoprenylated in bacteria with a farnesyl moiety or geranyl group, yielding a tricyclic proline-like core in the latter case ${ }^{10}$. Another unusual modification is produced in bacteria with metalloenzymes able to crosslink Lys and Trp side chains, to form macrocyclic peptides ${ }^{11}$. Within RiPPs, lanthipeptides, for instance, constitute an abundant family, some of which possess antimicrobial activities. Of note, a unique 5-ClTrp moiety, inserted through biocatalysis, is present in a clinical candidate with antimicrobial bioactivity. Here, the chlorine substituent is responsible for its increased ${ }^{12}$.

Tryptophan's scarce presence in proteins might be the ideal opportunity for selective derivatization, although it can also suffer from a poor accessibility when aiming at conjugation. For this latter strategy, tryptophan can be introduced by recombinant engineering. Trp can be abolished in a living organism via a surrogate noncanonical amino acid named L- $\beta$-(thieno[3,2-b]pyrrolyl)alanine $([3,2] T p a)^{13}$. This modification was later implemented in bioactive peptides by genetic code engineering ${ }^{14}$. The specific reactivity of this amino acid is an important challenge to overcome when addressing protein bioconjugation. Trp side chain labeling can be reached using malonaldehydes in harsh reaction conditions or by means of metallocarbenoids ${ }^{15}$. A relevant example was described by Hansen et al. ${ }^{16}$, performing chemo- and regioselective ethynylation of Trp-containing proteins. In addition to the outstanding selectivity obtained, the alkyne substituent can serve as a handle to undergo click chemistry or Pd-catalyzed Sonogashira reactions. Owing to the great interest in tryptophan bioconjugation and the raised concerns of the current methods, novel strategies continuously appear. Interestingly, a transition metal-free tryptophan-selective bioconjugation of proteins has recently been described ${ }^{17}$.

Natural cyclizations involving the Trp side chain mainly take place through 5-membered ring formation. For example, the Savige-Fontana tryptathionylation, gives way to a rigid bicyclic peptide cross-link utilizing Trp and Cys side chains ${ }^{18}$. Iodine-mediated Cys deprotection and formation of the Trp-Cys thioether bridge provided an analogous result ${ }^{19}$. Nevertheless, we developed an alternative strategy which involves conjugation and cyclization at the 6-membered ring. Given the broad interest in Trpbased chemistry, new synthetic strategies have been applied for the derivatization of the indole ring of tryptophan. Among all possible derivatization products, the halotryptophan motif is especially relevant due to its presence in natural bioactive compounds ${ }^{20,21}$. Introduction of halogens at different positions of the indole ring of tryptophan opens a gateway to new peptides with interesting properties. Moreover, access to these building blocks is realized by biotransformation of readily available starting materials. ${ }^{22}$ The potential fine-tuning of some properties such as the membrane permeability, biostability in human serum or fluorescence is highly significant in the future application of these building blocks in peptides. In addition to halogens, other interesting groups such as a cyano, azido or hydroxyl function are also quite relevant, and all of them can be obtained from the same precursor, namely a boronated $\operatorname{Trp}^{23}$.

Introduction of some Trp analogues in catalytic proteins has proved to be advantageous ${ }^{24}$. In this context, Trp has, for example, demonstrated its involvement in the catalysis of ligninolytic peroxidases ${ }^{25}$.

Of relevance to this work, halogenated peptides, as well as borylated ones, can also be used as synthetic precursors for Suzuki-Miyaura reactions. Taking advantage of the previously established methodology for on-resin Suzuki-Miyaura cross-coupling reactions ${ }^{22,26,27}$, bicyclic tryptophan-stapled peptides can be prepared as privileged peptide scaffolds involved in membrane transport.

John Wiley \& Sons, Inc. 


\section{METHODS:}

Protected amino acids were supplied by Iris Biotech (Marktredwitz, Germany). Wang ${ }^{\circledR}$ resin was obtained from PCAS BioMatrix Inc. (Quebec, Canada). DIEA, DIPCDI and ninhydrin were purchased from Fluka Chemika (Buchs, Switzerland) and HOAt from GL Biochem Shangai Ltd. (Shangai, China). Solvents for SPPS, such as DMF and DCM, were purchased from SDS (Barcelona, Spain) and trifluoroacetic acid (TFA) from Scharlau (Barcelona, Spain). Other chemical reagents were acquired from Aldrich (Milwaukee, WI) with the highest commercially available purity. Syringes of $20 \mathrm{ml}$ for SPPS and Eppendorf tubes were provided by Scharlau and Falcon tubes by Deltalab. PAMPA plates and system solution were supplied by pION (Woburn, MA USA), and porcine polar brain lipid extract (PBLEP) by Avantis Polar Lipids (Alabaster, AL). The basic instruments used were a lyophilizer (Virtis, Frezzmobile 25 EL), oven (Selecta, Digitronic), vortex [Merck Eurolab, MELB1719 (EU)], magnetic stirrer (IKA, RCT basic), centrifuge (Eppendorf, 5415R), GUTBOX тм (pION Aqueous Boundary Layer Thickness @ Double-Sink ${ }^{\mathrm{TM}}$ ), pipettes (Gilson, Pipetman P2, P20, P200, P1000) and Shimadzu UV-2501 PC UV-VIS spectrophotometer.

\section{Characterization of the peptides and purity assessment HPLC-analytical scale}

HPLC analyses were performed on a Waters Alliance 2695 with an automated injector and a photodiode array detector 2998 Waters (Waters, Milford, MA) using a SunFire ${ }^{\mathrm{TM}} \mathrm{C}_{18}$ column, $3.5 \mu \mathrm{m}, 4.6 \times 100 \mathrm{~mm}$. EmpowerPro 2 software was used to process the data. Detection was performed at $220 \mathrm{~nm}$. The analyses were carried out with a linear gradient of $\mathrm{CH}_{3} \mathrm{CN}\left(0.036 \%\right.$ TFA) in $\mathrm{H}_{2} \mathrm{O}(0.045 \%$ TFA) over 8 min at a flow rate of $1 \mathrm{ml} / \mathrm{min}$. High performance liquid chromatography purification was performed in a Waters system with 2545 binary gradient module, a 2767 manager collector, and a 2998 photodiode array detector with MassLynx 4.1 software. The column used was a Sunfire ${ }^{\mathrm{TM}} \mathrm{C} 18,3.5 \mu \mathrm{m}, 10 \times 150 \mathrm{~mm}$, $100 \AA$ from Waters. The solvents were prepared as $\mathrm{CH}_{3} \mathrm{CN}\left(0.1 \%\right.$ TFA) and $\mathrm{H}_{2} \mathrm{O}(0.1 \%$ TFA $)$. The flow rate was $10 \mathrm{ml} / \mathrm{min}$. Analytical HPLC analyses were performed to validate the correct purification of the peptide. Purity and identity was assessed by analytical UPLC-MS. Different gradients were explored to assess separation of the peak corresponding to the product from the impurities.

\section{UPLC}

UPLC analyses were performed on a Waters Acquity with an automated injector and a photodiode array detector Waters (Waters, Milford, MA) using a BEH $C_{18}$ column, $1.7 \mu \mathrm{m}, 2.1 \times 50 \mathrm{~mm}$. Data was processed with an EmpowerPro 3 software. Detection was performed at $220 \mathrm{~nm}$. The analyses were carried out with linear gradients $\mathrm{CH}_{3} \mathrm{CN}$, UPLC grade, $\left(0.036 \%\right.$ TFA) in $\mathrm{H}_{2} \mathrm{O}(0.045 \%$ TFA) over 2 min at a flow rate of $0.61 \mathrm{ml} / \mathrm{min}$.

\section{UPLC-ESI-MS}

UPLC-MS analyses were performed on a Waters Acquity with an automated injector and a photodiode array detector Waters (Waters, Milford, MA) coupled to an electrospray ion source ESI-MS Micromass ZQ. A BEH C ${ }_{18}$ column, $1.7 \mu \mathrm{m}, 2.1 \times 50 \mathrm{~mm}$ was used. Data were processed with Masslynx 4.1 software. The instrument was operated in the positive ESI (+) ion mode. Detection was performed at $220 \mathrm{~nm}$ and the analyses were carried out with linear gradients $\mathrm{CH}_{3} \mathrm{CN}$, UPLC grade, $\left(0.07 \%\right.$ formic acid) in $\mathrm{H}_{2} \mathrm{O}(0.1 \%$ formic acid) over $2 \mathrm{~min}$ at a flow rate of $0.61 \mathrm{ml} / \mathrm{min}$. Samples were introduced, in a volume (1-100 $\mu \mathrm{L})$ whose absorbance unit was between $0.2-0.4$, into the mass spectrometer ion source directly through an UPLC autosampler. 


\section{MALDI-TOF MS}

Mass spectrometry characterization of some peptides was carried out using a MALDI-TOF Applied Biosystem $4700.1 \mu \mathrm{L}$ of the peptide in a solution with a concentration around $1 \mathrm{mg} / \mathrm{mL}$ was mixed with $1 \mu \mathrm{L}$ of $\alpha$-cyano-4-hydroxycinnamic acid (ACH) matrix, and then seeded on the MALDI plate and airdried. For the matrix, $10 \mathrm{mg} / \mathrm{mL}$ solution of $\mathrm{ACH}$ was prepared in $\mathrm{CH}_{3} \mathrm{CN} / \mathrm{H}_{2} \mathrm{O} 1: 1(\mathrm{v} / \mathrm{v})$ with $0.1 \%$ TFA.

\section{LTQ-FT MS}

Some of the peptides were analysed using a high-resolution mass spectrometer to obtain their exact mass. Samples were dissolved in $200 \mu \mathrm{L}$ of $\mathrm{H}_{2} \mathrm{O}: \mathrm{CH}_{3} \mathrm{CN}$ and diluted in $\mathrm{H}_{2} \mathrm{O}: \mathrm{CH}_{3} \mathrm{CN} 1 \%$ formic acid for MS analysis. The analysis was performed in a LTQ-FT Ultra (Thermo Scientific) and the samples were introduced by automated nanoelectrospray. A NanoMate (Advion BioScience, Ithaca, NY, USA) infused the samples through the ESI Chip, which consists of 400 nozzles in a 20x20 array. Spray voltage was 1.7 $\mathrm{kV}$ and delivery pressure was $0.3 \mathrm{psi}$. MS conditions were: NanoESI, positive ionization, capillary temperature $200 \stackrel{\circ}{ } \mathrm{C}$, tube lens $119 \mathrm{~V}$, ion spray voltage $2 \mathrm{kV}$ and m/z 100-2000 amu. 500 console at 250 or $63 \mathrm{MHz}$ and 500 or $126 \mathrm{MHz}$, respectively. The deuterated solvent is mentioned for each product and spectrum. Chemical shifts $(\delta)$ are presented in parts per million (ppm), while coupling constants $(J)$ are given in Hertz $(\mathrm{Hz})$.
}

\section{General method for the solid-phase peptide synthesis}

Solid-phase peptide syntheses were performed at different scales between 100 and $500 \mu$ mols. L-amino acids were used except for D-proline. Peptide elongations were carried out in 20-ml polypropylene syringes, each fitted with a polypropylene porous disk. Solvents and soluble reagents were removed by filtration. Washings between steps were performed with DMF ( $3 \times 30 \mathrm{~s})$ and DCM ( $3 \times 30 \mathrm{~s})$ using $10 \mathrm{ml}$ of solvent/g resin each time. During couplings, the resin was stirred using an orbital shaker.

\section{Amino acid $\mathrm{H}-(\mathrm{XBr}) \mathrm{Trp}-\mathrm{OH} \mathrm{x}=5,6$ or 7}

The halotryptophans were prepared according to a reported biotransformation method ${ }^{22}$ and obtained as $\mathrm{HCl}$ salts. Briefly, the indole substrate $(2 \mathrm{mmol})$ and serine $(1.25$ equiv., $2.5 \mathrm{mmol})$ were suspended in $100 \mathrm{ml}$ buffer (100 mM potassium phosphate, adjusted to $\mathrm{pH} 7.8$ using $10 \mathrm{M}$ potassium hydroxide). The cell lysate $(3 \mathrm{ml})$, obtained as described in Smith et al. ${ }^{22}$ was transferred to dialysis tubing and gently placed in the reaction mixture. The reaction was incubated at $37{ }^{\circ} \mathrm{C}$ while shaking at $180 \mathrm{rpm}$ for 48 hours. The cellulose tubing was removed and washed with water. Unreacted indole was recovered by extraction with ethyl acetate $(2 \times 50 \mathrm{ml})$ and the aqueous phase was concentrated under reduced pressure to approximately $50 \mathrm{ml}$. The crude halotryptophans were purified by reverse-phase (RP) column chromatography with 97:3 and 0.5:99.5 methanol:water used as mobile phases. The reversephase column was packed in methanol and conditioned by passing $50 \mathrm{ml}$ of $20 \%, 40 \%, 60 \%, 80 \%$ and $100 \%$ water in methanol through the column sequentially, never allowing the column to run dry. A further $250 \mathrm{ml}$ water was passed through the column, after which the concentrated aqueous phase was loaded onto the column. $500 \mathrm{ml}$ water was passed through the column to remove salts, serine, and pyridoxal phosphate (PLP). Halotryptophans were eluted by passing $250 \mathrm{ml}$ methanol through the column, following which the solvent was removed under vacuum. The sample was then treated twice with $20 \mathrm{ml} 0.1 \mathrm{M}$ hydrochloric acid to convert the tryptophan to the hydrochloride salt, removing the solvent under reduced pressure. The salt was then dissolved in $50-100 \mathrm{ml}$ water and lyophlised to obtain the purified L-halotryptophan as a colourless, pink, yellow, or tan powder. 


\section{Characterization of 5-bromotryptophan ${ }^{22}$}

$\mathrm{HPLC} \mathrm{t}_{\mathrm{R}}$ : $10.7 \mathrm{~min} ; \mathrm{MS}(\mathrm{ESI}):\left[\mathrm{M}+\mathrm{H},{ }^{79} \mathrm{Br}\right]^{+}$expected $=283 ;\left[\mathrm{M}+\mathrm{H},{ }^{79} \mathrm{Br}\right]^{+}$found $=283,\left[\mathrm{M}+\mathrm{H},{ }^{81} \mathrm{Br}\right]^{+}$expected $=285$; $\left[\mathrm{M}+\mathrm{H},{ }^{81} \mathrm{Br}\right]_{\text {found }}^{+}=285 ;{ }^{1} \mathrm{H}$ NMR $\left(300 \mathrm{MHz}, \mathrm{D}_{2} \mathrm{O}\right): \delta 7.67(1 \mathrm{H}, \mathrm{d}, J=1.8), 7.30(1 \mathrm{H}, \mathrm{d}, J=8.7), 7.25-7.19$ $(2 \mathrm{H}, \mathrm{m}), 4.23(1 \mathrm{H}, \mathrm{dd}, J=7.1,5.5), 3.32(1 \mathrm{H}, \mathrm{dd}, J=15.4,5.4), 3.24(1 \mathrm{H}, \mathrm{dd}, 15.4,7.2) ;{ }^{13} \mathrm{C} \mathrm{NMR}(75 \mathrm{MHz}$, $\left.\mathrm{D}_{2} \mathrm{O}\right): 172.3,135.2,128.5,126.8,124.9,120.8,113.8,112.3,106.3,55.6,26.0$.

- Characterization of 6-bromotryptophan ${ }^{22}$

HPLC $t_{\mathrm{R}}$ : $10.8 \mathrm{~min} ; \mathrm{MS}(\mathrm{ESI}):\left[\mathrm{M}+\mathrm{H},{ }^{79} \mathrm{Br}\right]^{+}$expected $=283 ;\left[\mathrm{M}+\mathrm{H},{ }^{79} \mathrm{Br}\right]^{+}$found $=283,\left[\mathrm{M}+\mathrm{H},{ }^{81} \mathrm{Br}\right]^{+}$expected $=285$; $\left[\mathrm{M}+\mathrm{H},{ }^{81} \mathrm{Br}\right]^{+}{ }_{\text {found }}=285 ;{ }^{1} \mathrm{H}$ NMR $\left(300 \mathrm{MHz}, \mathrm{D}_{2} \mathrm{O}\right): \delta 7.55(1 \mathrm{H}, \mathrm{d}, J=1.7), 7.39(1 \mathrm{H}, \mathrm{d}, J=8.5), 7.18(1 \mathrm{H}, \mathrm{s})$, $7.15(1 \mathrm{H}, \mathrm{dd}, J=8.5,1.7), 4.24(1 \mathrm{H}, \mathrm{dd}, J=7.0,5.5), 3.35(1 \mathrm{H}, \mathrm{dd}, J=15.4,5.5), 3.27(1 \mathrm{H}, \mathrm{dd}, J=15.4$, 7.1); ${ }^{13}$ C NMR (75 MHz, D $\left.\mathrm{O}\right)$ : d 172.3, 137.3, 126.2, 125.8, 122.6, 119.8, 115.2, 114.8, 106.9, 53.6, 26.0.

- Characterization of 7-bromotryptophan ${ }^{22}$

HPLC $t_{R}$ : $10.7 \mathrm{~min}$; HRMS (ESI): 283.0077 calcd. for $\mathrm{C}_{11} \mathrm{H}_{11}{ }^{79} \mathrm{BrN}_{2} \mathrm{O}_{2} ;\left[\mathrm{M}+\mathrm{H},{ }^{79} \mathrm{Br}\right]^{+}$found $=283.0057$; 285.0057 calcd. for $\left.\mathrm{C}_{11} \mathrm{H}_{11}{ }^{81} \mathrm{BrN}_{2} \mathrm{O}_{2} ; \mathrm{M}+\mathrm{H},{ }^{81} \mathrm{Br}\right]^{+}$found $=285.0045 .{ }^{1} \mathrm{H}$ NMR $\left(300 \mathrm{MHz}, \mathrm{D}_{2} \mathrm{O}\right): \delta 7.54(1 \mathrm{H}, \mathrm{dd}$, $J=8.0,0.8), 7.36(1 \mathrm{H}, \mathrm{dd}, J=7.6,0.6), 7.26(1 \mathrm{H}, \mathrm{s}), 6.99(1 \mathrm{H}, \mathrm{t}, J=7.8), 4.25(1 \mathrm{H}, \mathrm{dd}, J=5.5,7.1), 3.38$ $(1 \mathrm{H}, \mathrm{dd}, J=5.3,15.7), 3.29(1 \mathrm{H}, \mathrm{dd}, J=7.0,15.5) ;{ }^{13} \mathrm{C} \mathrm{NMR}\left(75 \mathrm{MHz}, \mathrm{D}_{2} \mathrm{O}\right):$ d 172.4, 135.1, 128.2, 126.2, $124.8,121.0,117.9,108.1,104.8,53.7,26.2$.

\section{Amino acid derivatization Fmoc-(XBr)Trp-OH $x=5,6$ or 7}

The Fmoc-protected building blocks were synthesized according to the following procedure ${ }^{28}$ : The corresponding bromotryptophan hydrochloride salt $\left(500 \mathrm{mg}, 1.57 \mathrm{mmol}\right.$ ) was dissolved with $\mathrm{Na}_{2} \mathrm{CO}_{3}(1.2$ equiv., $1.89 \mathrm{mmol}$ ) in $10 \mathrm{ml} \mathrm{H}$ O. To this was added a solution of Fmoc-OSu (1.1 equiv., $1.72 \mathrm{mmol}$ ) in 10 $\mathrm{ml}$ dioxane. The reaction mixture was stirred overnight at room temperature. Reaction completion was checked by HPLC and the mixture was concentrated. The resulting aqueous phase was acidified with $1 \mathrm{~N}$ $\mathrm{HCl}(\mathrm{pH}=1)$ and extracted with $\mathrm{DCM}(4 \times 30 \mathrm{ml})$. The combined organic phase was washed with $1 \mathrm{~N} \mathrm{HCl}$, dried over $\mathrm{MgSO}_{4}$ and concentrated by rotary evaporation. The resultant crude was triturated with a mixture of DCM/hexane and filtered over a glass frit. The obtained pink solid was further purified with flash column chromatography (DCM/MeOH/AcOH 97:2:1, for $r_{\text {ref }}$ see individual compound) and concentrated to obtain white solids.

\section{- Characterization of Fmoc-5-bromotryptophan ${ }^{28}$}

HPLC $t_{R}$ : $18.9 \mathrm{~min}$; TLC $r_{\text {ref: }} 0.19$ (DCM/MeOH/AcOH 97:2:1); HRMS (ESI): 529.0556 calcd. for $\mathrm{C}_{26} \mathrm{H}_{20}{ }^{81} \mathrm{BrN}_{2} \mathrm{O}_{4} \mathrm{NaH}_{\mathrm{p}}{ }^{+} ;\left[\mathrm{M}+\mathrm{H}^{+}\right]_{\text {found }}=529.0552 ;{ }^{1} \mathrm{H}-\mathrm{NMR}\left(500 \mathrm{MHz}, \mathrm{DMSO}-\mathrm{d}_{6}\right): \delta \mathrm{H} 12.65(1 \mathrm{H}$, br s$), 11.06$ $(1 \mathrm{H}, \mathrm{s}), 7.87(2 \mathrm{H}, \mathrm{d}, \mathrm{J}=7.7 \mathrm{~Hz}), 7.75(1 \mathrm{H}, \mathrm{d}, \mathrm{J}=1.3 \mathrm{~Hz}), 7.70(1 \mathrm{H}, \mathrm{d}, \mathrm{J}=8.1 \mathrm{~Hz}), 7.63(2 \mathrm{H}, \mathrm{dd}, \mathrm{J}=15.6 \mathrm{~Hz}, 7.5$ $\mathrm{Hz}), 7.39(2 \mathrm{H}, \mathrm{q}, \mathrm{J}=7.1 \mathrm{~Hz}), 7.22-7.32(4 \mathrm{H}, \mathrm{M}), 7.17(1 \mathrm{H}, \mathrm{dd}, \mathrm{J}=8.5 \mathrm{~Hz}, 1.7 \mathrm{~Hz}), 4.14-4.22(4 \mathrm{H}, \mathrm{M}), 3.15$ $(2 \mathrm{H}, \mathrm{dd}, \mathrm{J}=14.5 \mathrm{~Hz}, 4.6 \mathrm{~Hz}), 2.99(2 \mathrm{H}, \mathrm{dd}, \mathrm{J}=14.5 \mathrm{~Hz}, 9.8 \mathrm{~Hz})$; Yield: $561 \mathrm{mg}(71 \%)$

\section{- Characterization of Fmoc-6-bromotryptophan ${ }^{28}$}

HPLC $t_{R}$ : $18.9 \mathrm{~min}$; TLC $r_{\text {ref }}$ : 0.16 (DCM/MeOH/ACOH 97:2:1); HRMS (ESI): 529.0556 calcd. for $\mathrm{C}_{26} \mathrm{H}_{20}{ }^{81} \mathrm{BrN}_{2} \mathrm{O}_{4} \mathrm{NaH}_{\mathrm{p}}{ }^{+} ;\left[\mathrm{M}+\mathrm{H}^{+}\right]_{\text {found }}=529.0579 ;{ }^{1} \mathrm{H}-\mathrm{NMR}\left(500 \mathrm{MHz}, \mathrm{DMSO}-\mathrm{d}_{6}\right): \delta \mathrm{H} 12.66(1 \mathrm{H}, \mathrm{br} \mathrm{s}), 10.98$ $(1 \mathrm{H}, \mathrm{s}), 7.87(2 \mathrm{H}, \mathrm{d}, \mathrm{J}=7.5 \mathrm{~Hz}), 7.62-66(3 \mathrm{H}, \mathrm{M}), 7.51(2 \mathrm{H}, \mathrm{M}), 7.37-41(2 \mathrm{H}, \mathrm{M}), 7.27(2 \mathrm{H}, \mathrm{M}), 7.19(1 \mathrm{H}, \mathrm{d}$, $\mathrm{J}=2.3 \mathrm{~Hz}), 7.09(1 \mathrm{H}, \mathrm{dd}, \mathrm{J}=8.3 \mathrm{~Hz}, 1.4 \mathrm{~Hz}), 4.15-4.22(4 \mathrm{H}, \mathrm{M}), 3.16(1 \mathrm{H}, \mathrm{dd}, \mathrm{J}=14.5 \mathrm{~Hz}, 4.5 \mathrm{~Hz}), 2.99(1 \mathrm{H}$, dd, J= $14.5 \mathrm{~Hz}, 9.8 \mathrm{~Hz}$ ); Yield: $589 \mathrm{mg}(75 \%)$

\section{- Characterization of Fmoc-7-bromotryptophan ${ }^{28}$}

HPLC $t_{R}$ : $19.3 \mathrm{~min}$; TLC $r_{\text {ref: }} 0.22$ (DCM/MeOH/AcOH 97:2:1); HRMS (ESI): 529.0556 calcd. for $\mathrm{C}_{26} \mathrm{H}_{20}{ }^{81} \mathrm{BrN}_{2} \mathrm{O}_{4} \mathrm{NaH}_{\mathrm{p}}{ }^{+} ;\left[\mathrm{M}+\mathrm{H}^{+}\right]_{\text {found }}=529.0511 ;{ }^{1} \mathrm{H}-\mathrm{NMR}(500 \mathrm{MHz}$, DMSO-d 6 ): $\delta \mathrm{H} 12.71(1 \mathrm{H}$, br s), 11.09 $(1 \mathrm{H}, \mathrm{s}), 7.86(2 \mathrm{H}, \mathrm{d}, \mathrm{J}=7.5 \mathrm{~Hz}), 7.70(1 \mathrm{H}, \mathrm{d}, \mathrm{J}=8.1 \mathrm{~Hz}), 7.64(1 \mathrm{H}, \mathrm{d}, \mathrm{J}=7.5 \mathrm{~Hz}), 7.61(1 \mathrm{H}, \mathrm{d}, \mathrm{J}=7.5 \mathrm{~Hz}), 7.58$ $(1 \mathrm{H}, \mathrm{d}, \mathrm{J}=7.9 \mathrm{~Hz}), 7.39(2 \mathrm{H}, \mathrm{m}), 7.24-7.31(4 \mathrm{H}, \mathrm{M}), 6.93(1 \mathrm{H}, \mathrm{t}, \mathrm{J}=7.7 \mathrm{~Hz}), 4.19-4.24(2 \mathrm{H}, \mathrm{M}), 4.17(2 \mathrm{H}, \mathrm{m})$, $3.19(1 \mathrm{H}, \mathrm{dd}, \mathrm{J}=14.5 \mathrm{~Hz}, 4.3 \mathrm{~Hz}), 3.19(1 \mathrm{H}, \mathrm{dd}, \mathrm{J}=14.5 \mathrm{~Hz}, 10.4 \mathrm{~Hz})$; Yield: $592 \mathrm{mg}$ (75\%)

John Wiley \& Sons, Inc. 


\section{Amino acid derivatization $p N Z-(\mathrm{XBr}) \operatorname{Trp}-\mathrm{OH} \mathrm{x}=5,6$ or 7}

The derivatized amino acid was prepared from $\mathrm{H}-(\mathrm{XBr}) \mathrm{Trp}-\mathrm{OH}$. $p$-Nitrobenzyl chloroformate (1 equiv.) was dissolved in dioxane $(3 \mathrm{ml})$. Sodium azide (1.2 equiv.), previously dissolved in $\mathrm{H}_{2} \mathrm{O}(2 \mathrm{ml})$, was added to this solution. This mixture was vigorously stirred at room temperature for $3 \mathrm{~h}$. The amino acid, dissolved in dioxane $(16 \mathrm{ml})$ and $2 \%$ aq. $\mathrm{NaHCO}_{3}(16 \mathrm{ml})$, was then introduced dropwise. The mixture was allowed to react for $24 \mathrm{~h}$ at room temperature. The $\mathrm{pH}$ was kept at 9-10 and readjusted when needed. Completion of the reaction was monitored by thin layer chromatography (TLC).

The crude product was separated in $\mathrm{H}_{2} \mathrm{O} /$ methyl-tert-butyl ether (MTBE) 1:1 (100 ml), and the aqueous phase was extracted with MTBE $(2 \times 50 \mathrm{ml})$. The $\mathrm{pH}$ was adjusted to 4 with aqueous $\mathrm{HCl} 12 \mathrm{~N}$. The products precipitated as yellow pale solids which were finally filtered, washed, resuspended in $\mathrm{H}_{2} \mathrm{O}$ and lyophilized.

\section{Cleavage conditions}

Peptides were cleaved from the CTC resin using a mixture of 2\% TFA in DCM (6x1 min) and from the Wang resin with 99:0.5:0.5 TFA/ $\mathrm{H}_{2} \mathrm{O} / \mathrm{TIS}$. The compounds were then filtrated and washed with DCM. After evaporating under vacuum, they were dissolved in $\mathrm{CH}_{3} \mathrm{CN}: \mathrm{H}_{2} \mathrm{O}$ and lyophilized.

\section{Head-to-tail cyclization in solution}

Cyclic peptides were prepared by treatment of the linear precursors with PyBOP (2 equiv.), HOAt (1 equiv.), DIEA (6 equiv.) in DCM/1\% DMF (final concentration $1 \mathrm{mM}$ ) at room temperature for 24-48 h. A final purification step by semipreparative HPLC on a $\mathrm{C}_{18}$ column was required to obtain the pure cyclic peptides.

\section{Characterization of the final peptides: cyclo(Lys-(5\&)Trp-Lys-(5\&)Trp-D-Pro)}

In the manuscript, we follow for brevity the nomenclature described in Spengler et al. ${ }^{29}$

The peptide was prepared using the standard methodology of García-Pindado et al. ${ }^{26} p \mathrm{NZ}-(5 \mathrm{Br}) \mathrm{Trp}-\mathrm{OH}$ and Fmoc- $(5 \mathrm{Br}) \operatorname{Trp}-\mathrm{OH}$ were used as the second and fourth amino acid, respectively. The synthesis was performed on solid-phase using $\mathrm{Fmoc} / \mathrm{tBu}$ chemistry. Miyaura borylation was carried out on-resin at the tripeptide level to form the boronic acid of the tryptophan derivative. Once the pentapeptide was obtained, the on-resin Suzuki reaction yielded the desired stapled peptide, bridged between the two tryptophan moieties. UPLC $t_{R}\left(G \quad 0-100 \% \mathrm{CH}_{3} \mathrm{CN} / \mathrm{H}_{2} \mathrm{O}\right.$ in $2 \mathrm{~min}$ ): $1.45 \mathrm{~min}$; UPLC-MS $\mathrm{t}_{\mathrm{R}}(\mathrm{G} \quad 0-100 \%$ $\mathrm{CH}_{3} \mathrm{CN} / \mathrm{H}_{2} \mathrm{O}$ in $\left.2 \mathrm{~min}\right): 1.68 \mathrm{~min},\left[\mathrm{M}+\mathrm{H}^{+}\right]_{\text {expected }}=710.90,\left[\mathrm{M}+\mathrm{H}^{+}\right]_{\text {found }}=709.30$, yield (synthesis+purification): $2 \%$

\section{cyclo(Lys-(6\&)Trp-Lys-(6\&)Trp-D-Pro)}

The peptide was prepared using the standard methodology of García-Pindado et al. ${ }^{26} p \mathrm{NZ}-(6 \mathrm{Br}) \mathrm{Trp}-\mathrm{OH}$ and Fmoc- $(6 \mathrm{Br}) \operatorname{Trp}-\mathrm{OH}$ were used as the second and fourth amino acid, respectively. The synthesis was performed on solid-phase using Fmoc/tBu chemistry. Miyaura borylation was carried out on-resin at the tripeptide level to form the boronic acid of the tryptophan derivative. Once the pentapeptide was obtained, on-resin Suzuki reaction yielded the desired stapled peptide between the two tryptophans.

UPLC $t_{R}\left(G \quad 0-100 \% \mathrm{CH}_{3} \mathrm{CN} / \mathrm{H}_{2} \mathrm{O}\right.$ in $2 \mathrm{~min}$ ): $1.44 \mathrm{~min}$; UPLC-MS $\mathrm{t}_{\mathrm{R}}\left(\mathrm{G} \mathrm{0-100 \%} \mathrm{CH}_{3} \mathrm{CN} / \mathrm{H}_{2} \mathrm{O}\right.$ in $2 \mathrm{~min}$ ): 1.69 $\min ,\left[\mathrm{M}+\mathrm{H}^{+}\right]_{\text {expected }}=710.90,\left[\mathrm{M}+\mathrm{H}^{+}\right]_{\text {found }}=709.80$, (synthesis+purification): $5 \%$

\section{cyclo(Lys-(7\&)Trp-Lys-(7\&)Trp-D-Pro)}

The peptide was prepared using the standard methodology of García-Pindado et al. ${ }^{26} p \mathrm{NZ}-(7 \mathrm{Br}) \operatorname{Trp}-\mathrm{OH}$ and Fmoc-(7Br) Trp-OH were used as the second and fourth amino acids, respectively. The synthesis was 
performed on solid-phase using Fmoc/tBu chemistry. Miyaura borylation was carried out on-resin at the tripeptide level to form the boronic acid of the tryptophan derivative. Once the pentapeptide was obtained, on-resin Suzuki reaction yielded the desired stapled peptide between the two tryptophans.

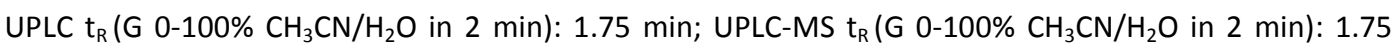
$\min ,\left[\mathrm{M}+\mathrm{H}^{+}\right]_{\text {expected }}=710.90,\left[\mathrm{M}+\mathrm{H}^{+}\right]_{\text {found }}=709.70$, yield (synthesis+purification): $3 \%$

\section{cyclo(Lys-(5Br)Trp-Lys-(5Br)Trp-D-Pro)}

The peptide was prepared from D-Pro-2-chlorotrityl resin (1 equiv. $0.58 \mathrm{mmol})$. Fmoc- $(5 \mathrm{Br}) \operatorname{Trp}-\mathrm{OH}$ and Fmoc-Lys(Boc)-OH residues ( 3 equiv.) were attached using DIPCDI (2 equiv. for Trp and 3 equiv. for Lys) and HOAt ( 2 equiv. for Trp and 3 equiv. for Lys) as coupling agents. Cleavage of the sequence from the resin with TFA/DCM 2:98 provided the desired peptide. Subsequently, the general cyclization method was used. Boc removal was performed with TFA/DCM 1:1 solution. The mixture was stirred at room temperature for $2 \mathrm{~h}$. The reaction was monitored by TLC (ACOEt/DCM 1:1) using the ninhydrin staining solution. The solvent was evaporated and the crude product was dissolved in $\mathrm{H}_{2} \mathrm{O} / \mathrm{CH}_{3} \mathrm{CN} 1: 1$ and lyophilized. UPLC $t_{R}\left(G 0-100 \% \mathrm{CH}_{3} \mathrm{CN} / \mathrm{H}_{2} \mathrm{O}\right.$ in $\left.2 \mathrm{~min}\right): 1.35 \mathrm{~min}$; UPLC-MS $\mathrm{t}_{\mathrm{R}}\left(\mathrm{G} 0-100 \% \mathrm{CH}_{3} \mathrm{CN} / \mathrm{H}_{2} \mathrm{O}\right.$ in 2 $\min ): 1.42 \mathrm{~min},\left[\mathrm{M}+\mathrm{H}^{+}\right]_{\text {expected }}=884.69,\left[\mathrm{M}+\mathrm{H}^{+}\right]_{\text {found }}=883.93$, HRMS (ESI): 882.22962 calcd. for $\mathrm{C}_{39} \mathrm{H}_{50} \mathrm{~N}_{9} \mathrm{O}_{5} \mathrm{Br}_{2} ;\left[\mathrm{M}+\mathrm{H}^{+}\right]_{\text {found }}=882.22829$; yield (synthesis + purification): $15 \%$

\section{cyclo(Lys-(6Br)Trp-Lys-(6Br)Trp-D-Pro)}

This peptide was prepared from D-Pro-2-chlorotritl resin (1 equiv. $=0.58 \mathrm{mmol})$. Fmoc- $(6 \mathrm{Br}) \operatorname{Trp}-\mathrm{OH}$ and Fmoc-Lys(Boc)-OH residues ( 3 equiv.) were attached using DIPCDI (2 equiv. for Trp and 3 equiv. for Lys) and HOAt ( 2 equiv. for Trp and 3 equiv. for Lys) as coupling agents. Cleavage of the sequence with TFA/DCM 2:98 provided the desired peptide. The general cyclization method was used. Boc removal was performed with TFA/DCM 1:1 solution. The mixture was stirred at room temperature for $2 \mathrm{~h}$. The reaction was monitored by TLC (ACOEt/DCM 1:1) using the ninhydrin staining solution. The solvent was evaporated and the crude product was dissolved in $\mathrm{H}_{2} \mathrm{O} / \mathrm{CH}_{3} \mathrm{CN} 1: 1$ and lyophilized. UPLC $\mathrm{t}_{\mathrm{R}}$ (G 0-100\% $\mathrm{CH}_{3} \mathrm{CN} / \mathrm{H}_{2} \mathrm{O}$ in $2 \mathrm{~min}$ ): $1.35 \mathrm{~min}$; UPLC-MS t $\mathrm{R}_{\mathrm{R}}\left(\mathrm{G} 0-100 \% \mathrm{CH}_{3} \mathrm{CN} / \mathrm{H}_{2} \mathrm{O}\right.$ in $2 \mathrm{~min}$ ): $1.42 \mathrm{~min},\left[\mathrm{M}+\mathrm{H}^{+}\right]_{\text {expected }}=$ 884.69, $\left[\mathrm{M}+\mathrm{H}^{+}\right]_{\text {found }}=883.99$, HRMS (ESI): 882.22962 calcd. for $\mathrm{C}_{39} \mathrm{H}_{50} \mathrm{~N}_{9} \mathrm{O}_{5} \mathrm{Br}_{2} ;\left[\mathrm{M}+\mathrm{H}^{+}\right]_{\text {found }}=882.22969$; yield (synthesis + purification): $15 \%$

\section{cyclo(Lys-(7Br)Trp-Lys-(7Br)Trp-D-Pro)}

This peptide was prepared from D-Pro-2-chlorotrityl resin (1 equiv. $=0.58 \mathrm{mmol}$ ). Fmoc-(7Br) Trp-OH and Fmoc-Lys(Boc)-OH residues ( 3 equiv.) were attached using DIPCDI ( 2 equiv. for Trp and 3 equiv. for Lys) and HOAt ( 2 equiv. for Trp and 3 equiv. for Lys) as coupling agents. Cleavage of the sequence with TFA/DCM 2:98 provided the desired peptide. The general cyclization method was used. Boc removal was performed with TFA/DCM 1:1 solution. The mixture was stirred at room temperature for $2 \mathrm{~h}$. The reaction was monitored by TLC (ACOEt/ DCM 1:1) using the ninhydrin staining solution. The solvent was evaporated and the crude product was dissolved in $\mathrm{H}_{2} \mathrm{O} / \mathrm{CH}_{3} \mathrm{CN}$ 1:1 and lyophilized. UPLC $\mathrm{t}_{\mathrm{R}}$ (G 0-100\% $\mathrm{CH}_{3} \mathrm{CN} / \mathrm{H}_{2} \mathrm{O}$ in $2 \mathrm{~min}$ ): $1.35 \mathrm{~min}$; UPLC-MS t $\mathrm{R}_{\mathrm{R}}\left(\mathrm{G} 0-100 \% \mathrm{CH}_{3} \mathrm{CN} / \mathrm{H}_{2} \mathrm{O}\right.$ in $\left.2 \mathrm{~min}\right): 1.42 \mathrm{~min},\left[\mathrm{M}+\mathrm{H}^{+}\right]_{\text {expected }}=$ 884.69, $\left[\mathrm{M}+\mathrm{H}^{+}\right]_{\text {found }}=883.99$, HRMS (ESI): 882.22962 calcd. for $\mathrm{C}_{39} \mathrm{H}_{50} \mathrm{~N}_{9} \mathrm{O}_{5} \mathrm{Br}_{2} ;\left[\mathrm{M}+\mathrm{H}^{+}\right]_{\text {found }}=882.22973$; yield (synthesis + purification): $10 \%$

\section{H-Lys-Trp-Lys-Trp-D-Pro-OH}

This peptide was prepared from D-Pro-2-chlorotrytil resin(1 equiv. $=0.58 \mathrm{mmol}$ ). Fmoc-Trp(Boc)-OH and Fmoc-Lys(Boc)-OH residues (3 equiv.) were attached using DIPCDI (3 equiv.) and HOAt (3 equiv.) as coupling agents. Cleavage of the sequence with TFA/DCM 95:5 provided the desired peptide. The mixture was evaporated and the crude product was dissolved in $\mathrm{H}_{2} \mathrm{O} / \mathrm{CH}_{3} \mathrm{CN}$ 1:1 and lyophilized. UPLC 
$t_{R}$ (G 0-100\% $\mathrm{CH}_{3} \mathrm{CN} / \mathrm{H}_{2} \mathrm{O}$ in $2 \mathrm{~min}$ ): $1.26 \mathrm{~min}$; UPLC-MS $\mathrm{t}_{\mathrm{R}}\left(\mathrm{G} 0-100 \% \mathrm{CH}_{3} \mathrm{CN} / \mathrm{H}_{2} \mathrm{O}\right.$ in $2 \mathrm{~min}$ ): $1.18 \mathrm{~min}$, $\left[\mathrm{M}+\mathrm{H}^{+}\right]_{\text {expected }}=744.90, \quad\left[\mathrm{M}+\mathrm{H}^{+}\right]_{\text {found }}=744.10, \quad \mathrm{HRMS} \quad(\mathrm{ESI}): 744.41916$ calcd. for $\mathrm{C}_{39} \mathrm{H}_{54} \mathrm{~N}_{9} \mathrm{O}_{6}$; $\left[\mathrm{M}+\mathrm{H}^{+}\right]_{\text {found }}=744.41898$; yield (synthesis + purification): $60 \%$

\section{cyclo(-Lys-Trp-Lys-Trp-D-Pro)}

This peptide was prepared from D-Pro-2-chlorotrytil resin (1 equiv.=mmol). Fmoc-Trp(Boc)-OH and Fmoc-Lys(Boc)-OH residues (3 equiv.) were attached using DIPCDI (3 equiv.) and HOAt ( 3 equiv.) as coupling agents. Cleavage of the sequence with TFA/DCM 2:98 provided the desired peptide. Cyclization was performed with the general method followed by Boc removal with TFA/DCM 1:1 solution. The mixture was stirred at room temperature for $2 \mathrm{~h}$. The reaction was monitored by TLC (ACOEt/DCM 1:1) using the ninhydrin staining solution. The solvent was evaporated and the crude product was dissolved in $\mathrm{H}_{2} \mathrm{O} / \mathrm{CH}_{3} \mathrm{CN}$ 1:1 and lyophilized. UPLC $\mathrm{t}_{\mathrm{R}}$ (G 0-100\% $\mathrm{CH}_{3} \mathrm{CN} / \mathrm{H}_{2} \mathrm{O}$ in $2 \mathrm{~min}$ ): $1.40 \mathrm{~min}$; UPLC-MS $\mathrm{t}_{\mathrm{R}}$ (G 0$100 \% \mathrm{CH}_{3} \mathrm{CN} / \mathrm{H}_{2} \mathrm{O}$ in $2 \mathrm{~min}$ ): $1.25 \mathrm{~min},\left[\mathrm{M}+\mathrm{H}^{+}\right]_{\text {expected }}=726.90,\left[\mathrm{M}+\mathrm{H}^{+}\right]_{\text {found }}=726.70$, HRMS (ESI): 726.40859 calcd. for $\mathrm{C}_{39} \mathrm{H}_{52} \mathrm{~N}_{9} \mathrm{O}_{5} ;\left[\mathrm{M}+\mathrm{H}^{+}\right]_{\text {found }}=726.40721$; yield (synthesis + purification): $50 \%$

\section{Parallel artificial membrane permeability assay (PAMPA)}

The PAMPA was used to measure the capacity of the peptides to cross membranes (such as the BBB) by passive diffusion. The effective permeability $\left(\mathrm{P}_{\mathrm{e}}\right)$ of the compounds was determined at an initial concentration of $200 \mu \mathrm{M}$. The buffer solution was prepared from a concentrated commercial one, supplied by pION. Following the manufacturer's instructions, system solution was adjusted to $\mathrm{pH} 7.4$ using a $0.5 \mathrm{M} \mathrm{NaOH}$ solution. The peptides were dissolved in a mixture of buffer solution with $20 \%$ of 1 propanol used as co-solvent. The PAMPA sandwich was separated, and the donor well was filled with $195 \mu \mathrm{L}$ of the compound solution of interest. A magnetic stirrer was placed in each well. The acceptor plate was put into the donor plate, ensuring that the underside of the membrane was in contact with the buffer. Then, $4 \mu \mathrm{L}$ of a mixture of phospholipids from a porcine polar brain extract $(20 \mathrm{mg} / \mathrm{ml})$ in dodecane (composition: $12.6 \%$ phosphatidylcholine (PC), 33.1\% phosphatidylethanolamine (PE), $18.5 \%$ phosphatidylserine (PS), $4.1 \%$ phosphatidylinositol (PI), $0.8 \%$ phosphatidic acid and $30.9 \%$ of other compounds) was added to the filter of each well, followed by $200 \mu \mathrm{L}$ of buffer solution. The plate was then covered and incubated at room temperature in a saturated humidity atmosphere for $4 \mathrm{~h}$ under orbital agitation at $25 \mu \mathrm{m}$ of unstirred water layer (UWL). After this period, $165 \mu \mathrm{L} /$ well of the solution from the donor and acceptor plates was transferred to the HPLC vials, except for the bicyclic compound, for which all the fractions were pooled. $100 \mu \mathrm{L}$ of each linear, stapled and cyclic acceptor samples and $80 \mu \mathrm{L}$ of the bicyclic acceptor were injected into the HPLC apparatus. Transport was also confirmed by HPLC-MS, which indicated that the integrity of the peptides was preserved. Regarding the donor and initial time samples, the linear compound was injected at $1 \mu \mathrm{L}$, the linear stapled peptide at $20 \mu \mathrm{L}$, the head-to-tail cyclic peptide at $10 \mu \mathrm{L}$, and the bicyclic peptide at $5 \mu \mathrm{L}$. The bicyclic acceptor was injected again at 1 and $5 \mu \mathrm{L}$ owing to the initial large absorbance obtained.

The effective permeability after $4 \mathrm{~h}$ was calculated using equation 1 and the percentage of transport using equation 2.

$$
T(\%)=\frac{C_{A}(t)}{C_{D}\left(t_{0}\right)} \cdot 100
$$

$$
P_{e}=\frac{-218.3}{t} \cdot \log \left[1-\frac{2 \cdot C_{A}(t)}{C_{D}\left(t_{0}\right)}\right] \cdot 10^{-6} \mathrm{~cm} / \mathrm{s}
$$

[Equation 2] 
where $t$ is time $(h), C_{A}(t)$ is the peptide concentration in the acceptor well at time $t$, and $C_{D}\left(t_{0}\right)$ is the peptide concentration in the donor well at $0 \mathrm{~h}$. Membrane retention (\%R) was calculated from the difference between the total starting amount of peptide and the amount of peptide in the donor and acceptor wells at the end of the assay after $4 \mathrm{~h}$.

\section{Stability in human serum}

Peptides at a final concentration of $3 \mathrm{mM}$ were dissolved in HBSS and incubated at $37^{\circ} \mathrm{C}$ in the presence of $90 \%$ human serum for $24 \mathrm{~h}$. At different incubation times ( $30 \mathrm{~min}, 1 \mathrm{~h}, 3 \mathrm{~h}, 6 \mathrm{~h}, 10 \mathrm{~h}, 12 \mathrm{~h}$ and $24 \mathrm{~h}$ ), $50 \mu \mathrm{L}$ aliquots were treated with $200 \mu \mathrm{L}$ of $\mathrm{MeOH}$ to precipitate serum proteins. After 30 min of centrifugation at $4{ }^{\circ} \mathrm{C}$, the supernatant was filtered and then analysed by HPLC to calculate the percentage of intact peptide in the sample.

\section{Cytotoxicity, XTT assay}

$5000 \mathrm{HeLa}$ cells were seeded in 96-well plates $24 \mathrm{~h}$ before starting the assay. After this period, cells with peptides at $200 \mu \mathrm{M}$ and $500 \mu \mathrm{M}$ in DMEM (1 mg/ml glucose) supplemented with $10 \%$ serum were incubated for $24 \mathrm{~h}$. Then, medium with peptides was removed and the XTT reagent was added to a final concentration of $0.5 \mathrm{mg} / \mathrm{ml}$. After a $3 \mathrm{~h}$ incubation, absorbance was measured at $475 \mathrm{~nm}$. The same measure was performed after $6 \mathrm{~h}$ incubation. Cell viability was calculated by dividing the absorbance of wells treated with a given peptide by the absorbance of the untreated wells. The $6 \mathrm{~h}$ incubation values were used for the calculations, since an absorbance higher than 2 is required to reach the plateau zone of fluorescence. Measurements were performed in triplicate. As a negative control, cells were incubated with medium and as positive control $1 \%$ of DMSO was introduced.

\section{RESULTS AND DISCUSSION:}

Encouraged by the notorious presence of halogenated tryptophans in natural products $9^{10}$, we aimed to study the effects of introducing this particular motif in a small size peptide sequence, containing five amino acids.

Design of the peptides

Within the current study, the core sequence was selected based on positive results obtained with a previously studied 'Phe analogue', i.e. H-Lys-Phe-Lys-Phe-D-Pro-OH. We selected a pentapeptide scaffold to carry out the cyclization since this number of amino acids yields macrocycles with some rigidity, after amide bond formation between the $N$ - and $C$ - termini. D-Proline was selected as $C$ terminal amino acid (i.e., anchorage point to the resin) to favor cyclization in solution by inducing a turn conformation ${ }^{30}$. Lysine incorporation provided good results in terms of passive diffusion permeability and poor membrane retention, as well as non-cytotoxicity in HeLa cells ${ }^{25}$. In this study, the phenyalanines were substituted by tryptophans that were suitably decorated with bromine, to yield head-to-tail cyclized and brominated peptides. Herein, the incorporation of Trp could positively influence peptide conformation and stability ${ }^{31}$. Moreover, the biaryl staple between two phenyalanines was extensively studied in our group and could be successfully replaced with a staple involving positions 5-5, 6-6 or 7-7 of two tryptophans. It is also worth mentioning that Trp-containing peptides with antimicrobial, and hence possibly membrane interfering, properties were reported ${ }^{22,32}$.

Head-to-tail cyclic pentapeptides displaying two tryptophans, brominated at the same position $(5,5 ; 6,6$ or 7,7 of the indole ring) were synthesized using standard Fmoc/tBu solid-phase peptide synthesis. We decided to introduce two identically substituted bromotryptophans to evaluate the potential effect of the indole substitution. The selected core sequence was exactly the same for all the peptides, i.e. H-Lys- 
Trp-Lys-Trp-D-Pro-OH. Cyclization, as well as incorporation of a D-amino acid may prevent proteolytic degradation of the peptidic scaffold, a common disadvantage of peptide therapeutics.

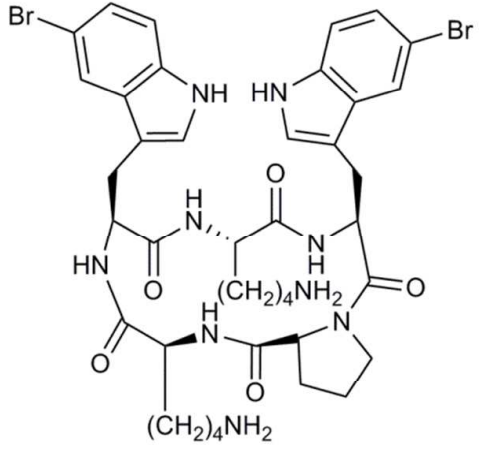

Monocyclic 5Br

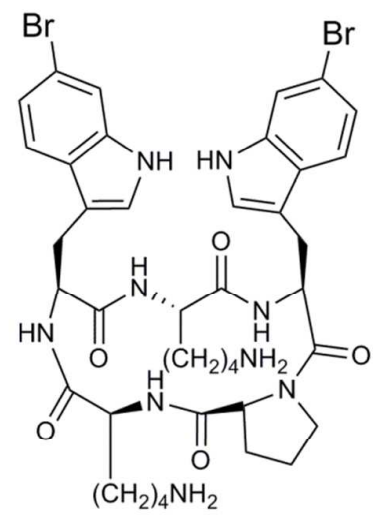

Monocyclic 6Br

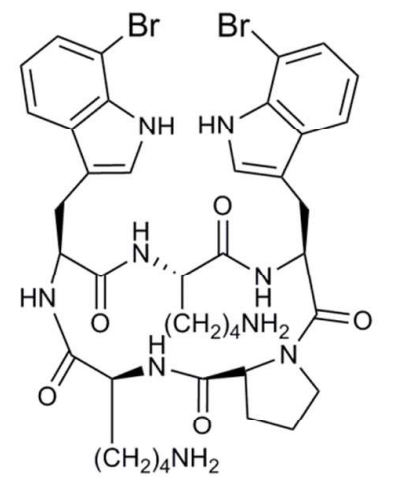

\section{Monocyclic 7Br}

FIGURE 1. Cyclic pentapeptides with $(5,5),(6,6)$ and $(7,7)$ bromotryptophans, named Monocyclic $5 \mathrm{Br}$, Monocyclic $6 \mathrm{Br}$ and Monocyclic $7 \mathrm{Br}$, respectively.

To determine the impact of bromine substitution, two control peptides were also prepared: cyclo(LysTrp-Lys-Trp-D-Pro) and H-Lys-Trp-Lys-Trp-D-Pro-OH; a head-to-tail cyclized peptide and a linear version with non-brominated tryptophans, resp. Furthermore, we carried out the synthesis of bicyclic peptides using the halogenated tryptophans as precursors to undergo Suzuki-Miyaura conversions in view of a Trp-Trp crosslink.
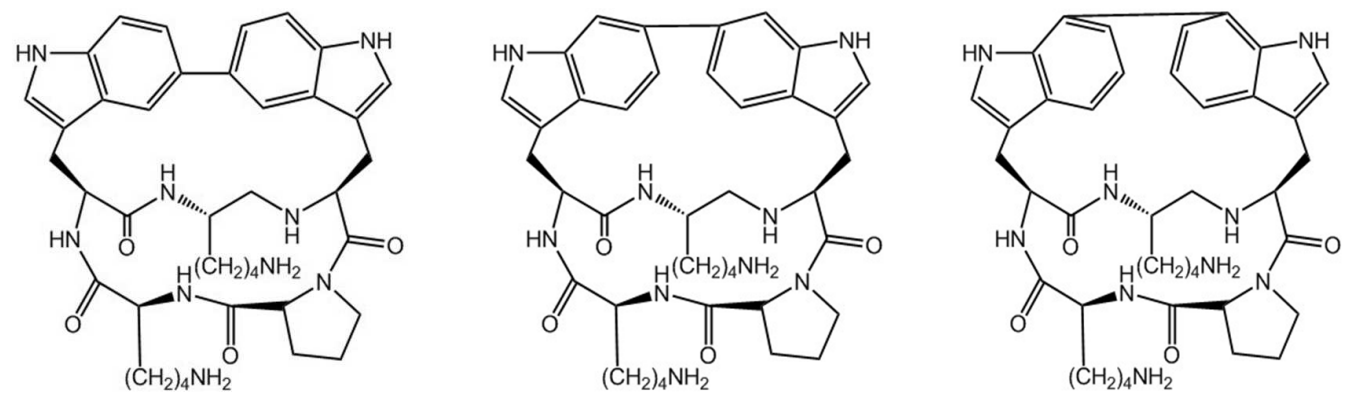


\section{$\begin{array}{lll}\text { Bicyclic 5,5 } & \text { Bicyclic 6,6 } & \text { Bicyclic 7,7 }\end{array}$}

FIGURE 2. Bicyclic pentapeptides with stapling between positions 5-5, 6-6 or 7-7 of tryptophan.

Bicyclic peptides have demonstrated to be privileged scaffolds that display improved pharmacological properties and prominent activities towards relevant biological targets ${ }^{33}$. Using our previously developed methodology for the preparation of bicyclic biaryl-containing pentapeptides ${ }^{11}$, we decided to prepare bicyclic peptides stapled between two tryptophans, at positions 5-5, 6-6 and 7-7 of the indole rings, taking advantage of the Suzuki-Miyaura reaction.

Briefly, the bicyclic peptides were prepared using a modified Fmoc/tBu strategy and applying Wang resin as solid support. At the tripeptide level, on-resin borylation was carried out using Trt as the temporary protecting group and $p N Z$ as the 'permanent' one. Once the tryptophan was borylated through a Miyaura borylation, Trt was removed and the peptide was elongated on the solid support. The pentapeptide was then subjected to an on-resin Suzuki-Miyaura reaction, having Boc as temporary protecting group and $p \mathrm{NZ}$ as the more permanent orthogonal one. Cleavage of the stapled precursor was carried out providing the peptide with side chain protecting groups on both lysines. After performing a pre-purification of the peptide and subsequent head-to-tail cyclization, removal of $p N Z$ was performed in solution yielding the desired stapled bicyclic peptide (Figure 3).

Furthermore, this new construct presents an interesting motif (i.e., two stapled tryptophans) that could be used when trying to target surface recognition, as was demonstrated for the biaryl feature ${ }^{11,12}$, due to the possible $\pi$-cation interactions with the tryptophan staple.

John Wiley \& Sons, Inc. 


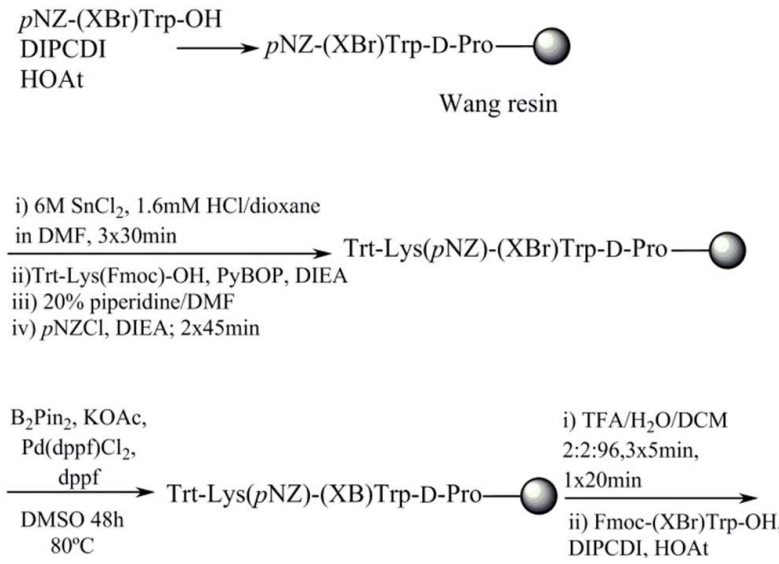

FIGURE 3. General methodology to synthesize 'Trp-Trp stapled' peptides based on the general methodology described by García-Pindado et al. ${ }^{11} \mathrm{X}=5,6,7$ denotes the position of $\mathrm{Br}$ in the indole of Trp. ' $\&$ ' corresponds to the cyclized positions (5-5, 6-6 or 7-7) between the two tryptophans.

Once the compounds were prepared, we aimed to evaluate their properties in terms of passive diffusion permeability, resistance towards proteolytic degradation and cytotoxicity.

\section{Passive diffusion permeability}

Owing to the special interest in peptide-based CNS drugs, these compounds were studied by PAMPA (Parallel Artificial Membrane Permeability Assay). The assay allows unveiling the potential passive diffusion permeability of these compounds across a mimic of the blood-brain barrier (BBB). We tested the three bromine-containing cyclic peptides and the bicyclic ones together with the two controls, obtaining the following results (Table 1, Figure 4). Propranolol was used as positive control of the assay. Cyclization of the linear peptide gave way to an enhanced permeability, also when performed in conjunction with the introduction of bromine at any of the studied positions of the indole ring of tryptophan.

$\mathrm{P}_{\mathrm{e}}$ represents the permeability of the investigated compounds across the artificial BBB, while $T$ stands for the percentage of transport of the peptides in the assay. These parameters allow to understand whether the tested compound show a relevant permeability through passive diffusion. An effective permeability higher than $1 \cdot 10^{-6} \mathrm{~cm} / \mathrm{s}$ correlates with a good transport prediction in vivo ${ }^{34}$. 
Upon comparison of the four head-to-tail cyclic peptides we observed an enhanced permeability when incorporating $5 \mathrm{Br}$-Trp and $6 \mathrm{Br}$-Trp, while in case of 7Br-Trp the permeability was slightly lower. These results demonstrated that halogens can be incorporated in a peptide and, in selected cases, this improves passive diffusion permeability. This tendency was previously reported by Malakoutikhak et $a l .{ }^{35}$ Nonetheless, it is worth noting the significant differences in the transport depending on the halogen position at the tryptophans, thus implying subtle changes in the properties of the brominecontaining cyclic peptides.

TABLE 1. Effective permeability and transport of the cyclic brominated peptides, bicyclic peptides, the cyclo(Lys-Trp-Lys-Trp-D-Pro) reference, and linear H-Lys-Trp-Lys-Trp-D-Pro-OH after $4 \mathrm{~h}$ assayed by PAMPA.

\begin{tabular}{lcc}
\hline \multicolumn{1}{c}{ Compound } & $\mathbf{P}_{\mathrm{e}}\left(\mathbf{x} 10^{6}\right) \mathbf{c m} / \mathbf{s}$ & $\mathbf{T}(\%) \mathbf{( 4 ~ h )}$ \\
\hline Monocyclic 5Br: cyclo(K(5Br)WK(5Br)Wp) & $4.7 \pm 0.4$ & $8.9 \pm 0.7$ \\
Monocyclic 6Br: cyclo(K(6Br)WK(6Br)Wp) & $4.6 \pm 0.1$ & $8.9 \pm 0.2$ \\
Monocyclic 7Br: cyclo(K(7Br)WK(7Br)Wp) & $1.3 \pm 0.6$ & $2.6 \pm 1.1$ \\
Head-to-tail cyclic: cyclo(KWKWp) & $2.7 \pm 0.2$ & $5.3 \pm 0.2$ \\
\hline Linear: H-KWKWp-OH & $0.1 \pm 3 \cdot 10^{-3}$ & $0.2 \pm 10^{-2}$ \\
\hline Bicyclic 5,5: cyclo(K(5\&)WK(5\&)Wp) & $3.8 \pm 1.9$ & $7.4 \pm 2.4$ \\
Bicyclic 6,6:cyclo(K(6\&)WK(6\&)Wp) & $3.7 \pm 0.6$ & $7.2 \pm 1.0$ \\
Bicyclic 7,7: cyclo(K(7\&)WK(7\&)Wp) & $7.6 \pm 1.0$ & $13.7 \pm 1.5$ \\
\hline
\end{tabular}
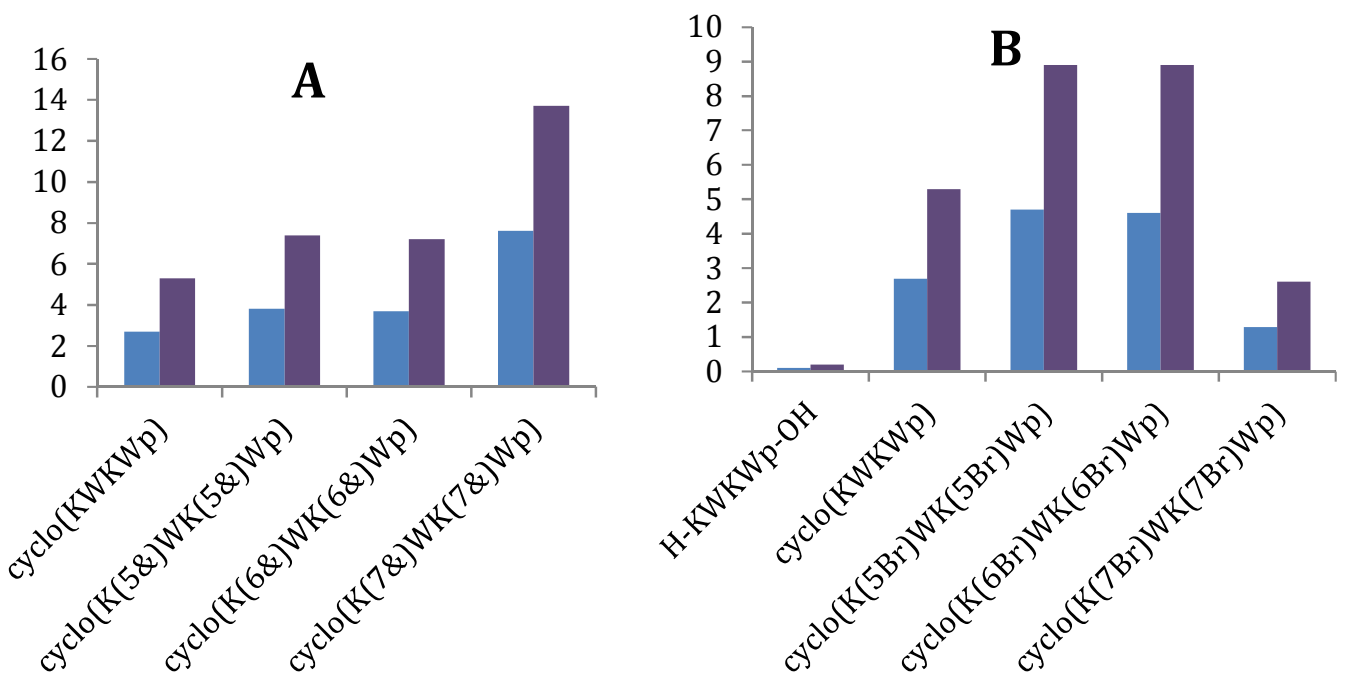

FIGURE 4. Effective permeability and transport after 4h in PAMPA. A) Comparison of cyclo(KWKWp) with the bicyclic peptides and B) Comparison of cyclo(KWKp) and linear $\mathrm{H}-\mathrm{KWKp}-\mathrm{OH}$ with the brominated peptides. In blue $\mathrm{P}_{\mathrm{e}}\left(\times 10^{6}\right) \mathrm{cm} / \mathrm{s}$ and in purple $\mathrm{T}(\%)(4 \mathrm{~h})$.

The bicyclic peptides did show a different behavior in terms of permeability. While bicyclic 5,5 and 6,6 displayed a slightly lower value of permeability, as compared to the monocyclic versions, bicyclic 7,7 demonstrated to have the highest BBB permeability. Therefore, we could not correlate the incorporation of the stapled constraint to an increased transport. The differences can arise from the constraint of the structures between the aromatic residues involved in the stapling. 
Regarding membrane retention, we did not observe a significant value for any of the head-to-tail cyclic versions. On the contrary, the linear control was mostly retained on the membrane. This result was not surprising since tryptophans as well as $N$ - and $C$ - termini are described to interact with membranes. Therefore, cyclization is suggested to be a tool to avoid high membrane retention due to the absence of these termini. However, this strategy could lead to lower transport of the final compounds owing to the loss of both polar groups.

\section{Cell viability assay}

We were especially concerned by the potential cytotoxicity of these peptides due to the presence of two bromines. Therefore, an XTT assay was performed at two different concentrations (200 $\mu \mathrm{M}$ and $500 \mu \mathrm{M})$ in HeLa cells.

As shown in Figure 5, no cytotoxicity could be directly attributed to the presence of bromine incorporation since complete cell survival was detected for both Monocyclic $6 \mathrm{Br}$ and Monocyclic $7 \mathrm{Br}$ peptides. Nevertheless, a relevant cell death was observed at $500 \mu \mathrm{M}$ for Cyclic $5 \mathrm{Br}$ peptide. Again, we observed a significantly different behavior of the bromine-containing peptides depending on the halogen substitution. Due to the obtained results, we discarded Monocyclic $5 \mathrm{Br}$ for the following studies.

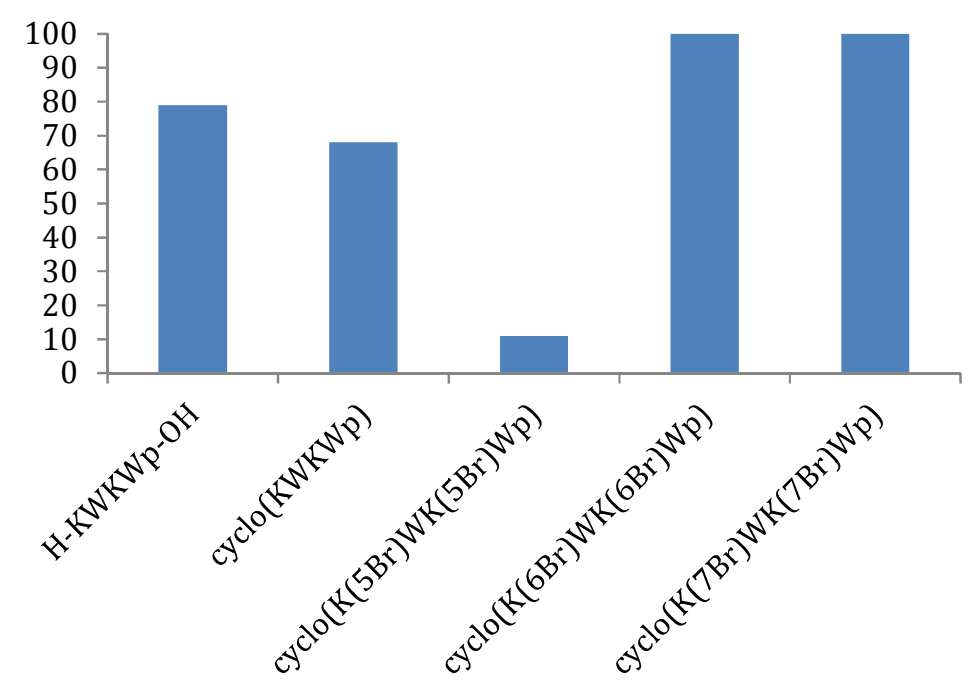

FIGURE 5. Cell viability assay at a concentration of $500 \mu \mathrm{M}$ of the peptides.

The high cytotoxicity of the Monocyclic $5 \mathrm{Br}$ peptide was an unexpected result that could be attributed to an altered conformation of the sequence. Depending on the brominated positions at the indole, the final peptide conformation can be significantly different. Computational studies on conformation distribution would be interesting in order to improve our knowledge about this result. It is also relevant to highlight that natural halogenation or hydroxylation of tryptophan occurs in both the 5- and 6positions.

\section{Protease resistance in human serum}

As previously mentioned, head-to-tail cyclization is a well-known strategy used to improve peptide biostability in human serum. After having prepared these compounds, it became interesting to determine which effect the incorporation of bromine shows in terms of protease resistance. Therefore, the peptides were incubated in human serum for $24 \mathrm{~h}$ and the different time-point aliquots were analyzed by HPLC to determine half-life times. We observed that all of the head-to-tail cyclized peptides, 
including the cyclic control, were stable for more than $3 \mathrm{~h}$ in human serum. Even though the incorporation of bromine could not be linked to increased serum stability, the insertion of bromotryptophan amino acids did not lead to a more rapid degradation of the cyclic peptide analogues. Here, the linear peptide was used as positive control of the assay, displaying a half-life close to $1 \mathrm{~h}$.

Earlier studies of our group ${ }^{26}$ demonstrated that the incorporation of an extra cyclization increases considerably the biostability in human serum. The published results demonstrated outstanding values of protease resistance, which can be quite beneficial. Nonetheless, owing to the minimum amount of the bicyclic peptides obtained, these were not subjected to stability assays.

\section{CONCLUSIONS}

This piece of work illustrates how the incorporation of bromotryptophan amino acids in cyclic peptides enables to improve passive diffusion permeability devoid of cytotoxicity, and presents an adequate resistance towards protease degradation. Not only can these compounds be of interest for biological purposes, but also the bromotryptophan motif can be used to prepare stapled bicyclic peptides, known as privileged scaffolds for recognition of protein surfaces.

\section{ACKNOWLEDGEMENTS}

This work was supported by MINECO-FEDER (BIO2016-75327-R) and the Generalitat de Catalunya (XRB and 2014-SGR-521). Júlia García was supported by an FPU grant (AP2012-6464). IRB Barcelona is the recipient of a Severo Ochoa Award of Excellence from MINECO. The IWT Flanders and Janssen Pharmaceutica are thanked for providing financial support of T.W. B.U.W.M ad S.B. thank the Research Foundation Flanders (FWO Vlaanderen; Scientific Research Network (WOG)).

1 Segraves, N. L.; Crews, P.; J. Nat. Prod. 2005, 68, 14841488.

2 Petersen, F. N. R.; Jensen, M. O.; Nielsen, C. H.; Biophysical Journal 2005, 89, 3985-3996.

3 Schiffer, M.; Chang, C. -H.; Stevens, F. J.; Protein Eng. 1992, 5, 213-214.

${ }^{4}$ Yau, W. -M.; Wimley, W. C.; Gawrish, K.; White, S. H.; Biochemistry 1998, 37, 14713-14718.

5 Ma, J. C.; Dougherty, D. A.; Chem. Rev. 1997, 97, 13031324.

${ }^{6}$ Gromiha, M. M.; Polymer 2005, 46, 983-990.

${ }^{7}$ Yang, B.; Wright, J.; Eldefrawi, M. E.; Pou, S.; MacKerell Jr., A.D.; J. Am. Chem. Soc. 1994, 116, 8722-8732.

8 Harries, W. E. C.; Khademi, S.; Stroud, R. M.; International Congress Series 2007, 1304, 15-21.

9 Arnison et al. Nat. Prod. Rep. 2013, 30, 108-160.

10 Okada, M.; Sugita, T.; Abe, I.; Beilstein JOC 2017, 13, 338-346.

${ }^{11}$ Schramma, K. R.; Seyedsayamdost, M. R.; ACS Chem. Biol. 2017, 12, 922-927.

12 Ortega, M. A.; Cogan, D. P.; Mukherjee, S.; Garg, N.; Li, B.; Thibodeaux, G. N.; Maffioli, S.; Donadio, S.; Sosio, M.; Escano, J.; Smith, L.; Nair, S. K.; van der Donk, W. A.; ACS Chem. Biol. 2017, 12, 548-557.
13 Hoesl, M. G.; Oehm, Sc. S.; Durkin, P.; Darmon, E.; Peil,

L.; Aerni, H-R.; Rappsilber, J.; Rinehart, J.; Leach, D.; Söll, D.; Budisa, N.; Agew. Chem. Int. Ed. 2015, 54, 10030-10034.

14 Kuthning, A.; Durkin, P.; Oehm, S.; Hoesl, M. G.; Budisa, N.; Süssmuth, R.; Scientific Reports 2016, 6, \#33447.

15 Koniev, O.; Wagner, A.; Chem. Soc. Rev. 2015, 44, 54955551.

16 Hansen, M. B.; Hubálek, F.; Skrydstrup, T.; Hoeg-Jensen, T.; Chem. Eur. J. 2016, 22, 1572-1576.

17 Seki, Y.; Ishiyama, T.; Sasaki, D.; Abe, J.; Sohma, Y.; Oisaki, K.; Kanai, M.; JACS 2016, 318, 10798-10801.

18 May, J. P.; Fournier, P.; Patrick, B. O.; Perrin, D. M.; Chem. Eur. J. 2008, 14, 3410-3417.

19 Schuresko, L. A.; Lockey, R. S.; Angew. Chem.. Int. Ed. 2007, 46, 3547-3549.

${ }^{20}$ Nettleton, D. E.; Doyle, T. W.; Krishnan, B.; Tetrahedron Lett. 1985, 26, 4011-4014.

21 El-Banna, N.; Winkelmann, G.; J. Appl. Microbiol. 1998, 85, 69-78.

${ }^{22}$ Smith, D. R. M.; Willemse, T.; Gkotsi, D. S.; Schepens, W.; Maes, B. U. W.; Ballet, S.; Goss, R. J. M.; Org. Lett. 2014, 16, 2622-2625.

23 Bartoccini, F.; Bartolucci, S.; Mari, M.; Piersanti, G.; Org. Biomol. Chem. 2016, 14, 10095-10100.

24 Agostini, F.; Völler, J-S.; Koksch, B.; Acevedo-Rocha, C. G.; Kubyshkin, V.; Budisa, N.; Angew. Chem. Int. Ed. 2017, 56, 9680-9703. 
25 Acebes, S.; Ruiz-Dueñas, F. J.; Toubes, M:; Sáez-Jiménez,

V.; Pérez-Boada, M.; Lucas, M. F.; Martínez, A. T.; Guallar,

V.; J. Phys. Chem. 2017, 121, 3946-3954.

${ }^{26}$ García-Pindado, J.; Royo, S.; Teixidó, M.; Giralt, E.; J. Pept. Sci. 2017, 23, 294-302.

27 Willemse, T.; Schepens, W.; van Vlijmen, H. W. T.; Maes,

B. U. W.; Ballet, S.; Catalysts 2017, 7, 74.

${ }^{28}$ Willemse, T. ; van Imp, K.; Goss, R. J. M.; van Vlijmen, H.

W. T.; Schepens, W.; Maes, B. U. W.; Ballet, S.;

Chem CatChem 2015, 7, 2055-2070.

${ }^{29}$ Spengler, J.; Jiménez, J. C.; Burger, K.; Giralt, E.; Albericio, F.; J. Peptide Res. 2005, 65, 550.

30 Klose, J.; Ehrlich, A.; Bienert, M.; Letters in Peptide Science 1998, 5, 129-131.

31 Mahalakshmi, R.; Sengupta, A.; Raghothama, S.; Shamala, N.; Balaram, P.; Biopolymers 2007,88, 36- 53.

32 Bittner, S.; Scherzer, R.; Harlev, E.; Amino Acids 2007, 33, 19-42.

33 Feliu, L.; Planas, M.; Int. J. Pept. Res. Ther. 2005, 11, 53.

34 Di, L.; Kerns, E. H.; Fan, K.; McConnell, O. J.; Carter, G. T.; Eur. J. Med. Chem. 2003, 38, 223-232.

35 Malakoutikhah, M.; Guixer, B.; Arranz-Gibert, P.; Teixidó, M.; Giralt, E.; ChemMedChem. 2014, 9, 1594-1601. 


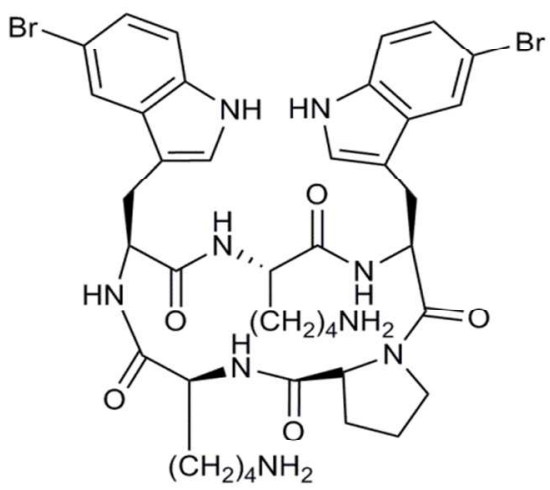

Monocyclic 5Br

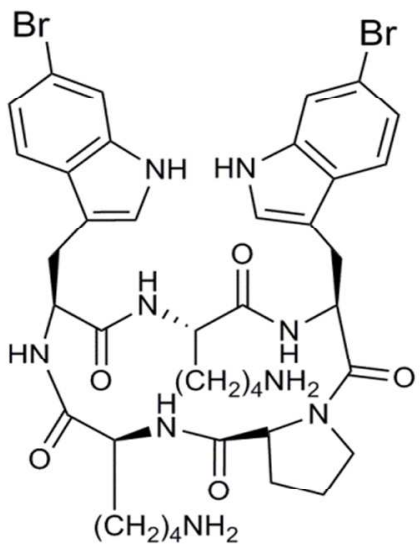

Monocyclic $6 \mathrm{Br}$

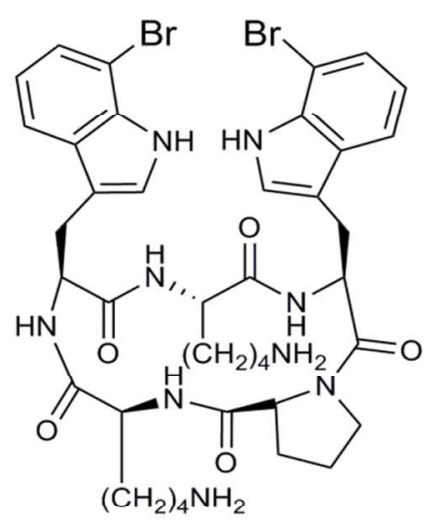

\section{Monocyclic 7Br}

FIGURE 1. Cyclic pentapeptides with $(5,5),(6,6)$ and $(7,7)$ bromotryptophans, named Monocyclic 5Br, Monocyclic $6 \mathrm{Br}$ and Monocyclic $7 \mathrm{Br}$, respectively.

$455 \times 455 \mathrm{~mm}(300 \times 300 \mathrm{DPI})$ 


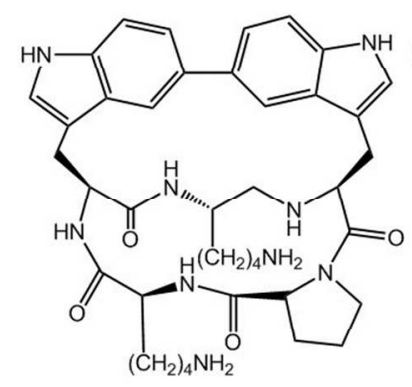

Bicyclic 5,5

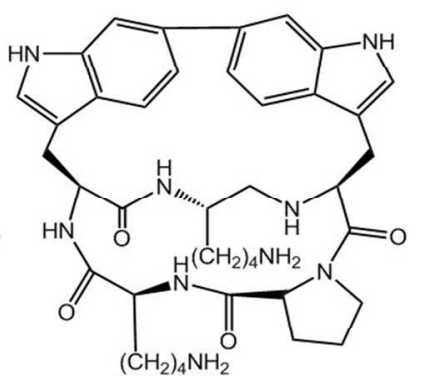

Bicyclic 6,6

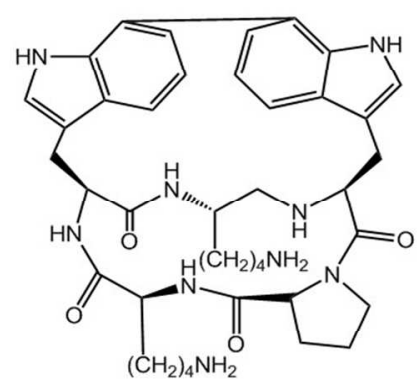

Bicyclic 7,7

FIGURE 2. Bicyclic pentapeptides with stapling between positions 5-5, 6-6 or 7-7 of tryptophan. $455 \times 455 \mathrm{~mm}(300 \times 300$ DPI $)$ 


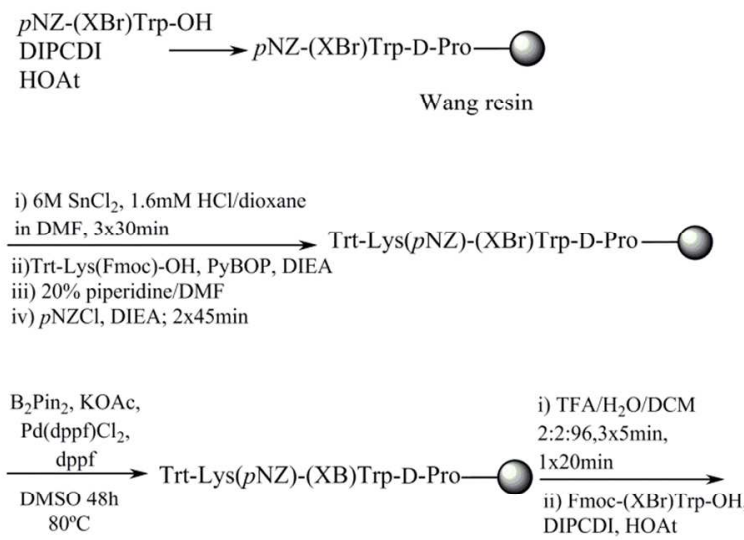

FIGURE 3. General methodology to synthesize 'Trp-Trp stapled' peptides based on the general methodology described by García-Pindado et al. 11 X=5,6,7 denotes the position of $\mathrm{Br}$ in the indole of Trp. ' $\&$ ' corresponds to the cyclized positions (5-5, 6-6 or 7-7) between the two tryptophans.

$455 \times 455 \mathrm{~mm}(300 \times 300 \mathrm{DPI})$ 

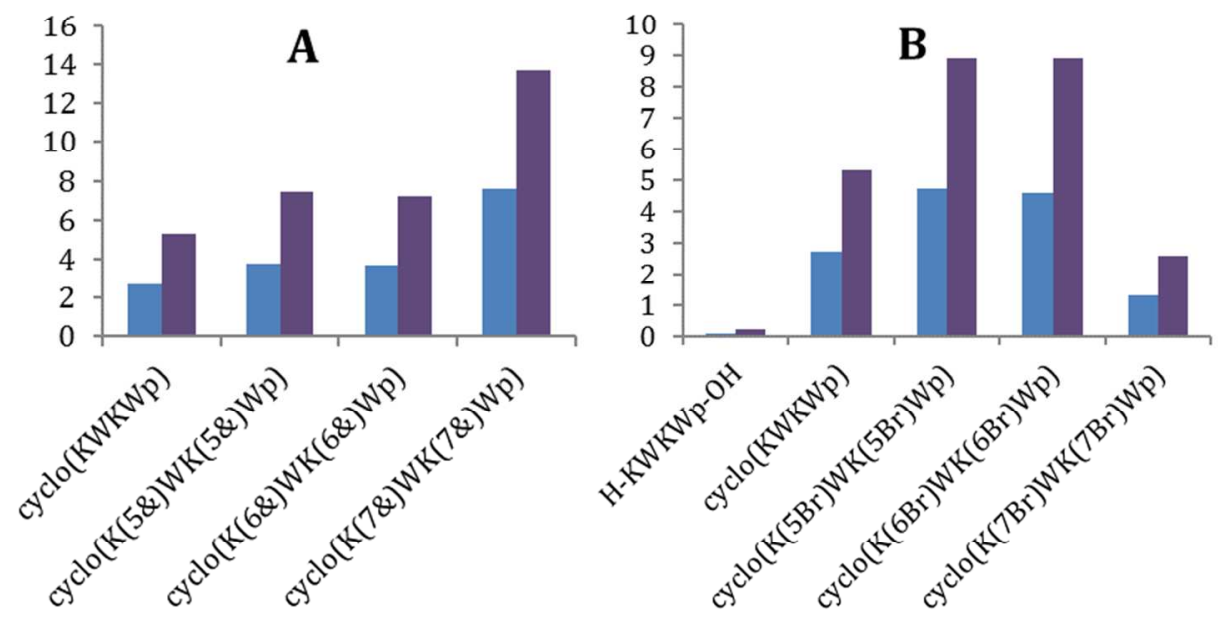

FIGURE 4. Effective permeability and transport after 4h in PAMPA. A) Comparison of cyclo(KWKWp) with the bicyclic peptides and $\mathrm{B}$ ) Comparison of cyclo $(\mathrm{KWKp})$ and linear $\mathrm{H}-\mathrm{KWKp}-\mathrm{OH}$ with the brominated peptides. In blue $\mathrm{Pe}(\mathrm{x} 106) \mathrm{cm} / \mathrm{s}$ and in purple $\mathrm{T}(\%)(4 \mathrm{~h})$.

$455 \times 455 \mathrm{~mm}(300 \times 300$ DPI $)$ 


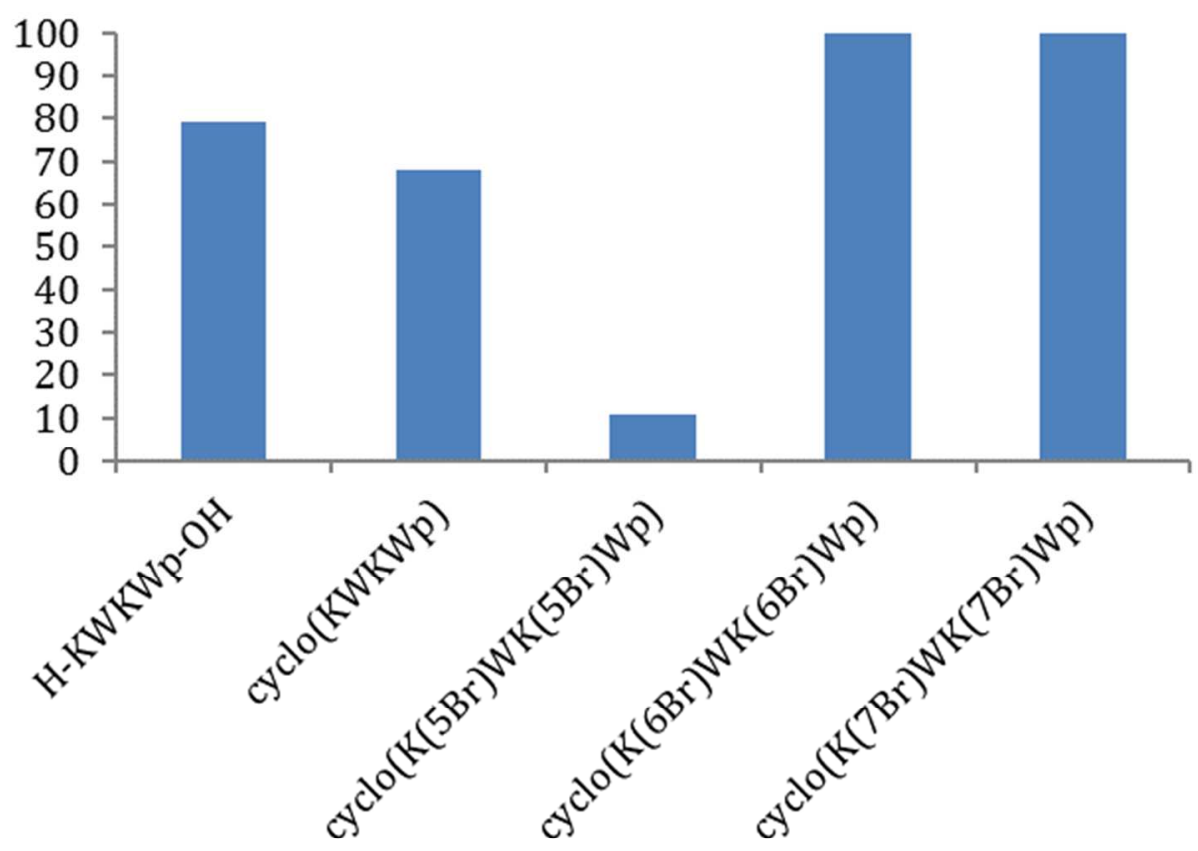

FIGURE 5. Cell viability assay at a concentration of $500 \mu \mathrm{M}$ of the peptides. $455 \times 455 \mathrm{~mm}(300 \times 300 \mathrm{DPI})$ 
TABLE 1. Effective permeability and transport of the cyclic brominated peptides, bicyclic peptides, the cyclo(Lys-Trp-Lys-Trp-D-Pro) reference, and linear H-Lys-Trp-Lys-Trp-D-Pro-OH after $4 \mathrm{~h}$ assayed by PAMPA.

$455 \times 455 \mathrm{~mm}(300 \times 300$ DPI $)$

John Wiley \& Sons, Inc. 